\title{
HUBUNGAN ASUPAN ZAT GIZI MIKRO DAN AKTIVITAS FISIK DENGAN FUNGSI KOGNITIF LANSIA DI PUSKESMAS KEBON JERUK JAKARTA BARAT
}

\section{The Relationship between Micronutrient Intake and Physical Activity with Elderly Cognitive Functions in Puskesmas Kebon Jeruk Jakarta Barat}

\author{
Harna $^{1^{*}}$, Jesi Arianti ${ }^{1}$, Rachmanida Nuzrina ${ }^{1}$ \\ ${ }^{1}$ Program Studi Gizi, Fakultas IImu-IImu Kesehatan, Universitas Esa Unggul \\ JI. Arjuna Utara No.9, Kebon Jeruk, Jakarta Barat, DKI Jakarta, Indonesia \\ *e-mail: harna@esaunggul.ac.id
}

Submitted: November 29 ${ }^{\text {th }}, 2019$, revised: May $4^{\text {th }}, 2020$, approved: May $12^{\text {th }}, 2020$

\begin{abstract}
Background. When we get older, the human body will experience the aging process, including the human brain. The human brain will get functional changes, including changes in the cognitive function where it becomes hard to remembering something, get difficulties in making a decision, and have slower action. Memory function is one of important intellectual components, because it is related to the quality of life. Many elderly experienced deteriorating abilities to remembering called dementia. Objective. The study aimed to understand the relationship between micronutrient intake and physical activity with elderly cognitive function. Method. This research used a crosssectional design, with 45 respondents from Bahagia Elderly Group's member in Puskesmas Kebon Jeruk, Jakarta Barat. The data collection was in December 2018. Cognitive function data collected by using a Mini Mental State Examination (MMSE) questionnaire, micronutrient intake data collected by using a food record, and physical activity data collected by using Physical Activities Scale for the Elderly Method (PASE). Results. Respondents aged 61-65 years with female sex was 55.6 percent. The average consumption of vitamin B6 was $1.547 \pm 0.315 \mathrm{mg}$, consumption of folic acid was $200.99 \pm 10.26 \mathrm{mcg}$, consumption of vitamin B12 was $1.796 \pm 0.193$ $\mathrm{mcg}$, an average of physical activity was $17.64 \pm 3.588$ point, history of the disease was $0.73 \pm 0.447$ point, and cognitive function was $25.01 \pm 3.103$ point. There was significant relationship between consumption of folic acid, consumption of vitamin B12 with cognitive function $(p<0.05)$. There was no relationship between consumption of vitamin B6, physical activity, and history of the disease with cognitive function ( $p>0.05)$. Conclusion. This study concluded that there was a relationship between the consumption of folic acid and vitamin B12 with cognitive function in the elderly. However, there was no relationship between vitamin B6 consumption, physical activity, and history of the diseases with the cognitive function.
\end{abstract}

Keywords: cognitive function, history of the disease, micronutrient, physical activity

\section{ABSTRAK}

Latar Belakang. Seiring bertambahnya usia, tubuh akan mengalami proses penuaan, termasuk otak. Otak akan mengalami perubahan fungsi, termasuk fungsi kognitif berupa sulit mengingat kembali, berkurangnya kemampuan dalam mengambil keputusan dan lebih lamban bertindak. Fungsi memori merupakan salah satu komponen intelektual yang paling utama, karena sangat berkaitan dengan kualitas hidup. Banyak lansia mengeluh kemunduran daya ingat yang disebut sebagai mudah lupa. Tujuan. Untuk mengetahui hubungan asupan zat gizi mikro dan aktivitas fisik dengan fungsi kognitif lansia. Metode. Penelitian ini menggunakan desain cross-sectional dengan sampel sebanyak 45 responden anggota Kelompok Lansia Bahagia di Puskesmas Kebon Jeruk, Jakarta Barat. Penelitian ini dilakukan pada bulan Desember 2018. Data fungsi kognitif diperoleh dengan menggunakan kuesioner Mini Mental State Examination (MMSE), 
data asupan menggunakan food record dan data aktivitas fisik diperoleh menggunakan metode Physical Activities Scale for the Elderly (PASE). Hasil. Responden berusia 61-65 tahun dengan jenis kelamin perempuan sebanyak 55,6 persen. Rata-rata asupan vitamin B6 yaitu 1,547 $\pm 0,315$ $\mathrm{mg}$, asupan asam folat yaitu $200,99 \pm 10,26 \mathrm{mcg}$, asupan vitamin B12 yaitu 1,796 $\pm 0,193 \mathrm{mcg}$, rata-rata aktivitas fisik yaitu $17,64 \pm 3,588$ poin, riwayat penyakit yaitu $0,73 \pm 0,447$ poin dan fungsi kognitif $25,01 \pm 3,103$ poin. Terdapat hubungan signifikan antara asupan asam folat, asupan vitamin B12, dengan fungsi kognitif $(p<0,05)$. Tidak terdapat hubungan antara asupan vitamin $B 6$, aktivitas fisik, dan riwayat penyakit dengan fungsi kognitif $(p>0,05)$. Kesimpulan. Penelitian ini menyimpulkan bahwa terdapat hubungan asupan asam folat dan vitamin B12 dengan fungsi kognitif pada lansia. Tetapi tidak terdapat hubungan antara asupan vitamin B6, aktivitas fisik, dan riwayat penyakit dengan fungsi kognitif.

Kata kunci: fungsi kognitif, riwayat penyakit, zat gizi mikro, aktivitas fisik

\section{PENDAHULUAN}

Jumlah orang lanjut usia (lansia) di seluruh dunia diperkirakan mencapai angka 500 juta dengan usia rata-rata 60 tahun dan diperkirakan akan mencapai angka 1,2 milyar pada tahun 2025. ${ }^{1}$ Bertambahnya jumlah lansia di Indonesia pada tahun 1990 sampai 2025 tergolong tercepat di dunia. Data Badan Pusat Statistik (BPS) menunjukkan bahwa penduduk lansia pada tahun 2000 berjumlah 14,4 juta jiwa, tahun 2013 berjumlah 23,9 juta jiwa, dan pada tahun 2020 akan berjumlah 28,8 juta jiwa. ${ }^{2}$

Perubahan yang dialami oleh lansia yaitu perubahan fisiologis, perubahan perilaku psikososial, dan perubahan kognitif. Orang berusia lanjut mengalami penurunan fungsi sel otak yang menyebabkan penurunan daya ingat jangka pendek, sulit berkonsentrasi, dan melambatnya proses informasi sehingga dapat mengakibatkan kesulitan berkomunikasi. Otak akan mengalami perubahan fungsi, termasuk fungsi kognitif berupa sulit mengingat kembali, berkurangnya kemampuan dalam mengambil keputusan, dan bertindak lebih lamban. ${ }^{3}$

Seseorang dikatakan mengalami penurunan fungsi kognitif yang lebih dikenal dengan demensia atau kepikunan, bila menunjukkan tiga atau lebih dari gejala-gejala berupa gangguan dalam hal perhatian (atensi), daya ingat (memori), orientasi tempat dan waktu, kemampuan konstruksi dan eksekusi (seperti mengambil keputusan, memecahkan masalah) tanpa adanya gangguan kesadaran. Gejala tersebut bisa disertai gangguan emosi, cemas, depresi, dan agresivitas. Demensia merupakan kemunduran progresif kapasitas intelektual yang disebabkan oleh gangguan pada otak. Saat ini sebanyak 35,6 juta orang di seluruh dunia mengalami demensia dan akan mencapai dua kali lipat setiap 20 tahun. Diperkirakan pada tahun 2050, penderita demensia di seluruh dunia mencapai 115,4 juta orang. ${ }^{4}$ Prevalensi kejadian demensia (per 1000 orang) di Indonesia pada tahun 2005 sebesar 191,4 insiden, pada tahun 2020 diperkirakan sebesar 314,1 insiden, dan akan meningkat pada tahun 2050 yaitu sekitar 932 insiden.

Penelitian sebelumnya yang dilakukan oleh Zulsita mengenai gambaran kognitif pada lansia menyebutkan sebanyak 34 persen responden mengalami penurunan fungsi kognitif. Perempuan lebih banyak mengalami penurunan fungsi kognitif daripada laki-laki, yaitu sebesar 45,7 persen. Penurunan fungsi kognitif terjadi 
pada 50 persen lansia tua (75-90 tahun), lebih banyak dibandingkan pada lansia (60-74 tahun) yaitu sebesar 27,7 persen. Berdasarkan status pendidikan, lansia dengan status pendidikan SD lebih banyak mengalami penurunan fungsi kognitif $(62,5 \%)$ dibandingkan lansia dengan status pendidikan lainnya. ${ }^{5}$

Vitamin B6, vitamin B12, dan asam folat merupakan zat gizi yang mempunyai peran penting dalam menjaga kesehatan saraf. Lansia dengan asupan vitamin B6 tinggi menunjukkan skor kognitif yang baik. Suplementasi asam folat dengan dosis tertentu pada lansia dapat mencegah penurunan fungsi kognitif, namun pada penelitian lain didapatkan hasil yang berlawanan, bahwa asupan tinggi asam folat mempercepat penurunan fungsi kognitif. Vitamin B12 dan asam folat melindungi pembuluh darah arteri dari kerusakan akibat pengaruh homosistein dengan cara mengubah homosistein menjadi sistein yang akhirnya dikeluarkan melalui urine. Homosistein merupakan asam amino sulfur yang terbentuk sebagai hasil demetilasi metionin. Kadar homosistein yang tinggi berhubungan dengan meningkatnya risiko serangan penyakit jantung, stroke, Alzheimer, dan menurunnya fungsi kognitif. ${ }^{6}$ Menurut Suter, asupan vitamin $\mathrm{B} 12$ berpengaruh pada jaringan saraf karena vitamin B12 berperan penting dalam metabolisme jaringan saraf, metabolisme semua sel, sumsum tulang, dan saluran cerna dengan mengubah folat menjadi bentuk aktif. Kekurangan vitamin B12 akan menurunkan fungsi kognitif. Vitamin B12 merupakan kofaktor dua enzim yaitu metionin dan metilmalonil-koA yang terjadi dalam mitokondria sel. Koenzim tersebut yang diperlukan dalam sistem saraf, sehingga gangguan saraf seperti depresi karena kekurangan vitamin B12 dapat disebabkan karena gangguan aktivitas enzim tersebut. ${ }^{7}$

Penelitian Triantari menyebutkan bahwa vitamin B6, vitamin B12, dan asam folat merupakan zat gizi yang memiliki peran penting dalam membantu metabolisme asam amino. Asam amino merupakan zat gizi penting dalam neurotransmiter. Asupan vitamin B6 yang tinggi berhubungan dengan skor kognitif. Suplementasi asam folat dengan dosis tertentu dapat mencegah penurunan fungsi kognitif seperti Alzheimer, demensia, dan depresi dengan cara mengontrol kadar homosistein dalam darah. ${ }^{8}$ Defisiensi vitamin B12 pada lansia berhubungan dengan lemahnya fungsi kognitif dan rendahnya nilai kemampuan bahasa dan ekspresi. Vitamin merupakan senyawa kimia yang sangat esensial bagi tubuh. Walaupun ketersediaan dalam tubuh hanya diperlukan dalam jumlah sedikit, namun manfaatnya sangat diperlukan untuk tubuh seperti mencegah timbulnya radikal bebas pada lansia dan bermanfaat untuk sistem imunitas pada lansia. ${ }^{9}$

Selain itu aktivitas fisik merupakan salah satu faktor yang berhubungan dengan fungsi kognitif. Beberapa studi menyebutkan bahwa lansia yang mengalami kesulitan melakukan pergerakan fisik atau tidak aktif memiliki perbedaan dalam jumlah skor fungsi kognitifnya. ${ }^{10}$ Aktivitas fisik mempunyai pengaruh yang bermanfaat pada fungsi kognitif saat usia lanjut dan juga merupakan pencegahan terhadap gangguan fungsi kognitif dan demensia. Penelitian Sinambela menyatakan bahwa aktivitas fisik dapat mencegah atau memperlambat onset dari penurunan fungsi kognitif atau demensia. ${ }^{11}$

Berdasarkan hasil penelitian Sinambela, diperoleh rata-rata asupan asam folat 146,65 
mcg dengan $(p<0,05)$ sehingga terdapat hubungan antara asupan asam folat dengan fungsi kognitif pada lansia di Werdha Wisma Mulia Kowani. Selain itu, dari uji ini juga diketahui nilai $r=0,361$ yang artinya variabel asupan asam folat dan fungsi kognitif memiliki kekuatan hubungan sedang. ${ }^{11}$ Beberapa penelitian telah membuktikan hubungan antara asupan zat gizi mikro dengan fungsi kognitif. Namun demikian, beberapa penelitian menunjukkan hasil yang berbeda, bahwa intervensi vitamin $B$ dan asam folat tidak berhubungan dengan peningkatan fungsi kognitif pada lansia. ${ }^{12,13}$ Oleh sebab itu, peneliti tertarik untuk melakukan kajian masalah tersebut. Penelitian ini bertujuan untuk mengetahui hubungan asupan zat gizi mikro dan aktivitas fisik dengan fungsi kognitif lansia pada kelompok Lansia Bahagia di Puskesmas Kebon Jeruk, Jakarta Barat.

\section{METODE}

Jenis penelitian adalah penelitian kuantitatif dengan menggunakan desain cross-sectional. Penelitian dilaksanakan pada bulan Desember 2018 di Puskesmas Kebon Jeruk, Jakarta Barat. Penentuan sampel menggunakan teknik total sampling yaitu teknik pengambilan sampel sama dengan populasi. Populasi penelitian adalah seluruh lansia pada Kelompok Lansia Bahagia di Puskesmas Kebon Jeruk, Jakarta Barat yang berjumlah 45 orang. Penelitian ini telah lolos etik di Komisi Etik Penelitian Universitas Esa Unggul dengan nomor: 0499-18.447/DPKE-KEP/FINALEA/UEU/XII/2018.

Pengumpulan data meliputi data identitas sampel, data kognitif, data aktivitas fisik, data riwayat penyakit, data asupan vitamin $\mathrm{B} 6$, asam folat, dan vitamin B12. Data fungsi kognitif diperoleh dengan menggunakan kuesioner Mini Mental State Examination (MMSE) yang terdiri dari 11 pertanyaan, dan setiap pertanyaan memiliki skor 1-5 untuk nilai fungsi kognitif. ${ }^{14}$ Penghitungan aktivitas pada individu menggunakan metode Physical Activities Scale for The Elderly (PASE) yaitu penilaian aktivitas dengan memberikan pertanyaan-pertanyaan tentang jenis aktivitas selama tujuh jam terakhir. Data asupan vitamin B6, asam folat, dan vitamin B12 diperoleh melalui wawancara dengan menggunakan food record.

Analisis data meliputi analisis univariat dan bivariat. Analisis univariat dilakukan untuk memperoleh gambaran distribusi dari masing-masing variabel independen maupun dependen sehingga akan menghasilkan tabel distribusi frekuensi. Analisis bivariat digunakan untuk menganalisis hubungan (vitamin B6, asam folat, vitamin B12) dan aktivitas fisik terhadap fungsi kognitif pada kelompok lansia bahagia di Puskesmas Kebon Jeruk, Jakarta Barat. Semua variabel pada analisis bivariat menggunakan skala ukur data rasio. Analisis data menggunakan uji korelasi pearson setelah dilakukan uji normalitas.

\section{HASIL}

\section{Karakteristik Responden}

Responden dalam penelitian ini adalah seluruh lansia pada Kelompok Lansia Bahagia di Puskesmas Kebon Jeruk, Jakarta Barat. Sebanyak 55,6 persen responden berjenis kelamin perempuan dan 44,4 persen berjenis kelamin laki-laki. Mayoritas responden berusia 61-65 tahun dengan persentase 53,3 persen. Sebanyak 44,4 persen responden berpendidikan SMA, seperti yang ditunjukkan pada Tabel 1. 
Tabel 1. Karakteristik Responden

\begin{tabular}{ccc}
\hline \multicolumn{1}{c}{ Variabel } & $\mathrm{n}$ & $\%$ \\
\hline Usia & 21 & \\
$55-60$ & 24 & 56,7 \\
$61-65$ & & \\
Jenis Kelamin & 25 & 55,6 \\
Perempuan & 20 & 44,4 \\
Laki-laki & & \\
Pendidikan & 4 & 8,9 \\
SD & 8 & 17,8 \\
SMP & 20 & 44,4 \\
SMA & 4 & 8,9 \\
D3 & 9 & 20 \\
S1 & & \\
\hline
\end{tabular}

Tabel 2 menunjukkan bahwa rata-rata fungsi kognitif pada lansia adalah 25,31 pada rentang usia 55-65 tahun, dengan nilai fungsi kognitif terendah 19 poin dan nilai fungsi kognitif tertinggi 30 poin. Rata-rata asupan vitamin B6 adalah $1,547 \mathrm{mg}$ dengan asupan terendah $1,1 \mathrm{mg}$ dan asupan tertinggi $2,5 \mathrm{mg}$ dengan standar deviasi 0,31 . Rata-rata asupan asam folat adalah 200,99 mcg dengan asupan terendah 181,1 mcg dan asupan tertinggi $217,5 \mathrm{mcg}$ dengan standar deviasi 10,26. Rata-rata asupan vitamin B12 adalah 1,80 mcg dengan nilai terendah 1,4 mcg dan asupan tertinggi 2,1 mcg dengan standar deviasi 0,18 . Sebagian besar asupan vitamin B6 berada dalam kategori cukup yaitu 62,2 persen. Sebagian besar asupan vitamin B12 responden termasuk dalam kategori kurang yaitu sebesar 75,6 persen dan terdapat 35,6 persen dengan asupan asam folat yang cukup. Berdasarkan hasil penilaian aktivitas fisik yang dilakukan, rata-rata aktivitas fisik pada lansia adalah 17,644 dengan nilai terendah 10 dan nilai tertinggi 24 .

Tabel 2. Asupan Vitamin B6, Asam Folat, Vitamin B12, Aktifitas Fisik, Riwayat Penyakit, dan Fungsi Kognitif

\begin{tabular}{lcc}
\hline \multicolumn{1}{c}{ Variabel } & Mean $\pm S D$ & Min-Maks \\
\hline Fungsi kognitif & $25,31 \pm 3,103$ & $19-30$ \\
Asupan vitamin B6 & $1,547 \pm 0,315$ & $1,1-2,5$ \\
Asupan asam folat & $200,99 \pm 10,26$ & $181,1-217,5$ \\
Asupan vitamin B12 & $1,796 \pm 0,193$ & $1,4-2,1$ \\
Aktivitas fisik & $17,64 \pm 3,588$ & $10-24$ \\
\hline
\end{tabular}


Hubungan Asupan Vitamin B6, Asam Folat, Vitamin B12, Aktivitas Fisik, dan Riwayat Penyakit terhadap Fungsi Kognitif

Hasil penelitian menunjukkan bahwa tidak ada hubungan yang signifikan antara asupan vitamin B6 dengan fungsi kognitif pada kelompok Lansia Bahagia di Puskesmas Kebon Jeruk, Jakarta Barat $(p>0,05)$ dengan nilai kekuatan 0,213 yang berarti memiliki hubungan sedang dengan arah positif. Terdapat hubungan yang signifikan antara asupan asam folat dengan fungsi kognitif pada Kelompok Lansia Bahagia di Puskesmas Kebon Jeruk, Jakarta Barat $(p<0,05)$ dengan nilai kekuatan 0,734 yang berarti memiliki hubungan kuat dengan arah positif.

Terdapat hubungan yang signifikan antara asupan vitamin B12 dengan fungsi kognitif pada Kelompok Lansia Bahagia di Puskesmas Kebon Jeruk, Jakarta Barat dengan nilai $p$-value yang didapatkan adalah $0,001(p<0,05)$ dengan nilai kekuatan 0,576 yang berarti memiliki hubungan kuat dengan arah positif.

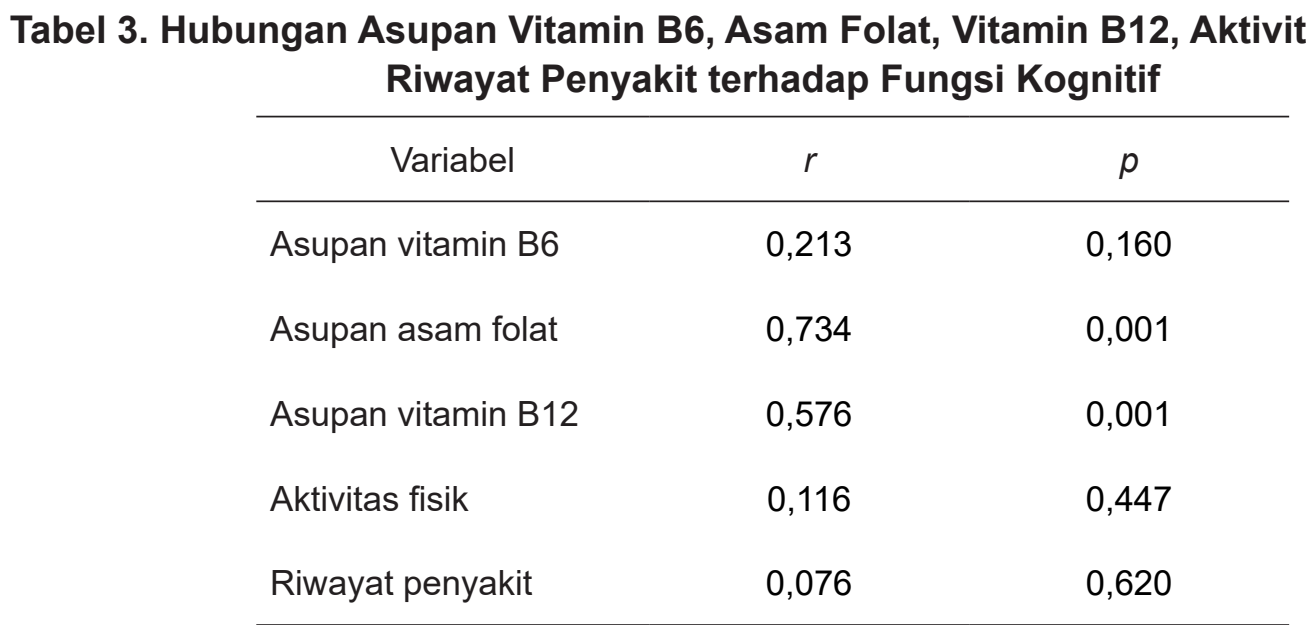

Tabel 3 menunjukkan bahwa tidak terdapat hubungan yang signifikan antara aktivitas fisik dengan fungsi kognitif pada kelompok Lansia Bahagia di Puskesmas Kebon Jeruk, Jakarta Barat $(p>0,05)$ dengan nilai kekuatan 0,116 yang berarti memiliki hubungan sangat rendah dengan arah positif. Tidak terdapat hubungan yang signifikan antara riwayat penyakit dengan fungsi kognitif pada Kelompok Lansia Bahagia di Puskesmas Kebon Jeruk, Jakarta Barat $(p>0,05)$ dengan nilai kekuatan 0,076 yang berarti memiliki hubungan sangat rendah dengan arah positif.

\section{PEMBAHASAN}

Fungsi kognitif merupakan aktivitas mental secara sadar, seperti berpikir, mengingat, belajar, dan menggunakan bahasa. Fungsi kognitif juga merupakan kemampuan daya ingat, pertimbangan, pemecahan masalah, merencanakan, menilai, mengawasi, dan melakukan evaluasi. ${ }^{8}$ Pada penelitian ini, terdapat 22,2 persen responden yang mengalami gangguan kognitif ringan dan terdapat 77,8 persen responden dengan fungsi kognitif normal. Berdasarkan hasil penilaian fungsi kognitif diketahui bahwa rata-rata fungsi kognitif lansia pada rentang usia 55-65 tahun adalah 25,31 poin, dengan nilai fungsi kognitif terendah 19 poin dan nilai fungsi kognitif tertinggi 30 poin, dengan standar deviasi 3,102. Hasil penelitian ini menunjukkan gambaran fungsi kognitif lebih baik dibandingkan penelitian Maryati et al, yang menunjukkan bahwa 46,7 persen lansia di UPT Panti Werdha Mojopahit, Kabupaten Mojokerto mengalami perubahan fungsi kognitif berat. ${ }^{15}$

Penelitian ini menunjukkan bahwa tidak terdapat hubungan signifikan antara asupan vitamin B6 dengan fungsi kognitif. Temuan ini 
sejalan dengan hasil penelitian Triantari yang menunjukkan bahwa tidak ada hubungan bermakna antara asupan vitamin B6 dengan fungsi kognitif. ${ }^{8}$ Secara teori, status kognitif tidak hanya dipengaruhi oleh asupan vitamin B6 tetapi dapat dipengaruhi oleh faktor lain seperti usia, tingkat pendidikan, kebiasaan merokok, dan pekerjaan.

Hasil penelitian ini tidak sejalan dengan penelitian Pratiwi et al, yang menunjukkan bahwa terdapat hubungan negatif yang signifikan antara tingkat kecukupan vitamin B1, B2, dan B6 dengan kejadian demensia $(p<0,05)$. Hal ini berarti semakin rendah tingkat kecukupan vitamin maka fungsi kognitif juga akan rendah. Rendahnya asupan vitamin B6 pada penelitian ini kemungkinan bisa disebabkan karena kurangnya nafsu makan responden. Hal ini didukung oleh penelitian yang dilakukan oleh Pratiwi et al, bahwa lansia kemungkinan mengalami nafsu makan yang kurang, bisa disebabkan karena masakan yang disajikan tidak memiliki rasa, tidak enak, atau memiliki tekstur keras sehingga mempengaruhi asupan vitamin B6. ${ }^{16}$

Vitamin B6 merupakan vitamin larut dalam air yang sangat penting untuk pemeliharaan sel darah merah, sistem saraf, dan sistem kekebalan tubuh. Vitamin B6 tersedia dalam bahan makanan sumber hewani dan nabati. Bahan makanan yang tinggi vitamin B6 diantaranya daging tepung, sayur, kacang, dan sereal. ${ }^{17}$

Piridoksal 5-phosphate (PLP) adalah kofaktor dalam banyak reaksi metabolisme asam amino. Oleh karena itu dibutuhkan banyak enzim tubuh vitamin B6 dapat mencegah penyakit Parkinson ataupun penyakit demensia jenis lain hingga 50 persen, merawat autis, mual di pagi hari, dan membantu mengendalikan reaksi alergi. Vitamin B6 diabsorpsi di usus halus. Vitamin tersebut di dalam hati, ginjal, dan otak difosforilasi kembali kemudian diubah oleh enzim oksidase. Perubahan fosforilasi dan perubahan oksidatif juga dapat terjadi di dalam sel darah merah yang terikat oleh hemoglobin. Sebanyak 50 persen vitamin ini disimpan dalam otot. ${ }^{6}$

Vitamin B6 juga merupakan homocysteine remetilasi kofaktor penting dan defisiensi dikaitkan dengan peningkatan kadar homosistein darah. Homosistein merupakan faktor risiko untuk penyakit serebrovaskular dan juga mungkin memiliki efek toksik langsung pada neuron dari sistem saraf pusat. Gangguan neuropsikiatrik termasuk kejang, migrain, sakit kronis, dan depresi telah dikaitkan dengan kekurangan vitamin B6. Berdasarkan teori, vitamin B6 berperan sebagai koenzim berupa PLP dalam keadaan difosforilasi dan piridoksimal fosfat (PMP) dalam reaksi transminasi dekarboksilasi dan reaksi lainnya yang berkaitan dengan metabolisme protein. Dekarboksilasi dari piridoksal fosfat menghasilkan berbagai bentuk amina seperti epinefrin, norepinefrin dan serotonin yang penting untuk fungsi otak. ${ }^{18}$

Hasil penelitian ini menunjukkan bahwa terdapat hubungan yang signifikan antara asupan asam folat dengan fungsi kognitif. Nilai korelasi ( $r$ ) yang positif menunjukkan bahwa semakin tinggi asupan asam folat maka semakin baik fungsi kognitif pada Kelompok Lansia Bahagia di Puskesmas Kebon Jeruk, Jakarta Barat. Hasil penelitian ini sejalan dengan penelitian yang dilakukan oleh Ravaglia et al, yang menyatakan bahwa kadar asupan asam folat rendah berhubungan dengan meningkatnya risiko kejadian demensia dan Alzheimer. ${ }^{19}$ Penelitian ini didukung oleh penelitian lain yang menunjukkan bahwa asupan asam folat berhubungan dengan perbaikan fungsi kognitif melalui penurunan homocysteine (Hcy), vascular care, perbaikan status inflamasi, dan respon sebagai antioksidan..$^{20-22}$

Asam folat adalah vitamin yang termasuk dalam kelompok vitamin B dan merupakan salah satu unsur penting dalam sintesis deoxyribonucleic acid (DNA). Unsur ini diperlukan sebagai koenzim dalam sintesis pirimidin. Folat 
tersebar luas pada berbagai tumbuh-tumbuhan dan jaringan hewan. Asam folat mempunyai sifat termo labil dan larut dalam air sehingga seringkali folat dari bahan-bahan makanan tersebut rusak karena proses memasak. ${ }^{19}$

Hasil penelitian menunjukkan bahwa terdapat hubungan signifikan antara vitamin B12 dengan fungsi kognitif lansia. Hasil penelitian ini sejalan dengan beberapa penelitian lainnya yang menunjukkan bahwa kekurangan vitamin B12 atau rendahnya konsentrasi vitamin B12 di dalam plasma berhubungan dengan kemunduran fungsi kognitif. 6,23,24 Pemberian suplemen vitamin B12 selama dua bulan dapat meningkatkan fungsi kognitif lansia. ${ }^{25}$

Vitamin B12 terlibat dalam satu karbon metabolisme yang berperan dalam transfer kelompok metil dan reaksi metilasi yang penting untuk sintesis dan metabolisme neurotransmitter dan fosfolipid dalam sistem saraf pusat. Selain itu, vitamin B12 diperlukan untuk sintesis asam nukleat, hematopoesis, metabolisme asam lemak, dan asam amino dalam siklus asam sitrat di mitokondria. Hasil penelitian ini didukung oleh penelitian sebelumnya bahwa rendahnya asupan vitamin B12 menyebabkan tingginya kadar homosistein darah, sehingga dapat mempercepat penurunan status kognitif pada lansia. Hasil penelitian ini menunjukkan bahwa lansia laki-laki cenderung mengalami gangguan kognitif lebih banyak. Hal ini dapat disebabkan karena lansia laki-laki memiliki kebiasaan merokok sejak usia anak-anak hingga lansia. Hasil penelitian ini sesuai dengan penelitian sebelumnya bahwa rendahnya asupan vitamin B12 dan asam folat berhubungan dengan kejadian penurunan gangguan kognitif pada lansia. ${ }^{21}$ Penelitian ini tidak sejalan dengan hasil penelitian Sinambela yang menyatakan bahwa tidak terdapat hubungan signifikan antara asupan vitamin B12 dengan fungsi kognitif pada lansia. ${ }^{11}$ Suplementasi vitamin B12 tidak memberikan efek pencegahan pada fungsi kognitif lansia. ${ }^{26}$ Menurut Suter, asupan vitamin B12 berpengaruh pada jaringan saraf karena fungsi vitamin B12 salah satunya berperan penting dalam metabolisme jaringan saraf, metabolisme semua sel, sumsum tulang, dan saluran cerna dengan jalan mengubah folat menjadi bentuk aktif. Kekurangan vitamin B12 akan menurunkan fungsi kognitif. ${ }^{7}$

Hasil penelitian menunjukkan tidak terdapat hubungan signifikan antara aktivitas fisik dengan fungsi kognitif lansia. Hal ini menunjukkan bahwa responden kurang melakukan aktivitas fisik. Penurunan pergerakan dapat dipengaruhi oleh penurunan massa tulang dan kandungan kalsium tubuh. Kondisi ini akan meningkat seiring dengan menopause pada perempuan. Aktivitas fisik yang ringan dilakukan oleh 6,7 persen responden, sedangkan aktivitas fisik sedang dilakukan oleh 60 persen responden, dan aktivitas fisik berat dilakukan oleh 33,3 persen responden. Aktivitas fisik menstimulasi pertumbuhan saraf yang kemungkinan dapat menghambat penurunan fungsi kognitif pada lansia. ${ }^{25}$ Hasil penelitian ini tidak sejalan dengan studi meta analisis yang dilakukan oleh Blondell et al yang menunjukkan bahwa peningkatan aktivitas fisik dapat menurunkan risiko penurunan fungsi kognitif. ${ }^{27}$

Hasil penelitian menunjukkan bahwa tidak terdapat hubungan signifikan antara riwayat penyakit dengan fungsi kognitif lansia. Hal ini kemungkinan disebabkan berbagai faktor lain yang mempengaruhi seperti faktor lingkungan, gaya hidup (pola makan, aktivitas fisik, dan stres), dan genetik. Berbagai penyakit yang diderita oleh lansia termasuk penyakit infeksi dan penyakit degeneratif. ${ }^{28}$ Penelitian ini sejalan dengan penelitian Pratiwi et al, yang menunjukkan tidak terdapat hubungan positif signifikan $(p>0,05)$ antara riwayat penyakit diabetes mellitus dengan kejadian demensia. ${ }^{16}$ 


\section{Kesimpulan}

Berdasarkan hasil penelitian ini dapat disimpulkan bahwa terdapat hubungan asupan asam folat dan asupan vitamin B12 dengan fungsi kognitif pada Kelompok Lansia Bahagia di Puskesmas Kebon Jeruk, Jakarta Barat. Hal ini menunjukkan bahwa asupan vitamin B12 dan asam folat yang cukup dapat meningkatkan fungsi kognitif lansia, sehingga diperlukan peningkatan pengetahuan bagi masyarakat terkait konsumsi zat gizi mikro, terutama vitamin B12 dan asam folat.

\section{SARAN}

Kelompok lansia perlu memperhatikan asupan zat gizi mikro terutama asupan vitamin B, sehingga dapat memperbaiki fungsi kognitif atau menurunkan gejala gangguan fungsi kognitif. Selain itu disarankan untuk melakukan aktivitas fisik. Penulis menyarankan agar penelitian ini dapat dilanjutkan dengan melakukan intervensi produk tinggi vitamin B12 dan asam folat untuk pencegahan gangguan fungsi kognitif pada kelompok lansia.

\section{UCAPAN TERIMA KASIH}

Ucapan terima kasih disampaikan kepada Kelompok Lansia Bahagia di Kebon Jeruk, Jakarta Barat yang telah bersedia menjadi responden penelitian, sehingga penelitian dapat terlaksana dengan baik.

\section{DAFTAR PUSTAKA}

1. Sengkey $A H$, Mulyadi $N$, Bawotong J. Hubungan Depresi dengan Interaksi Sosial Lanjut Usia di Desa Tombasian Atas Kecamatan Kawangkoan Barat. Jurnal Keperawatan. 2017; 5(1):1-5.

2. Badan Pusat Statistik 2010. Data Statistik Indonesia. Jumlah Penduduk menurut Kelompok Umur, Jenis Kelamin, Provinsi, dan Kabupaten/Kota. Diakses dari https:// www.bps.go.id// tanggal 21 Januari 2019.
3. Agustia S, Sabrian F, Woferst R. Hubungan Gaya Hidup dengan Fungsi Kognitif pada Lansia. JOM PSIK. 2014;1(2):1-8.

4. Mavrodaris A, Powell J, Thorogood M. Prevalences of Dementia and Cognitive Impairment among Older People in SubSaharan Africa: A Systematic Review. Bulletin of the World Health Organization. 2013;91(10): 773-83.

5. Zulsita A. Gambaran Kognitif pada Lansia di RSUP H. Adam Malik Medan dan Puskesmas Petisah Medan. Skripsi. Medan: Fakultas Kedokteran Universitas Sumatera Utara, 2007.

6. Clarke R, Birks J, Nexo E, Ueland PM, Schneede J, Scoot J, et al. Low Vitamin B-12 Status and Risk of Cognitive Decline in Older Adults. Am J Clin Nutr. 2007;86(5):1384-91.

7. Suter PM. Vitamin Metabolisme and Requirements in Erderly: Selected Aspect. In: Chernoff R, editor. Geriatric Nutrition: The Health Professional's Handbook. Canada: Jones and Barlett Publisher; 2006.

8. Triantari R. Hubungan Asupan Vitamin B6, Vitamin B12, Asam Folat, Aktivitas Fisik, dan Kadar Homosistein dengan Status Kognitif Lansia. Skripsi. Semarang: Program Studi IImu Gizi Fakultas Kedokteran Universitas Diponegoro, 2011.

9. Santoso TB, Rohmah ASN. Gangguan Gerak dan Fungsi Kognitif pada Wanita Lanjut Usia. Jurnal Kesehatan. 2011;4(1):41-57.

10. Rockwood K, Middleton L. Physical Activity and the Maintenance of Cognitive Function. Alzheimers Dement. 2007;3(2):38-44.

11. Sinambela MP. Hubungan Asupan Zat Gizi (Protein, Vitamin A, Asam Folat, Vitamin B12, dan Vitamin C) dan Fungsi Kognitif pada Lansia di Panti Werdha Wisma Mulia Kowani Jakarta Barat Tahun 2018. Skripsi. Jakarta: Fakultas IImu Kesehatan Universitas Esa Unggul, 2018. 
12. Ford AH, Almeida OP. Effect of Vitamin B Supplementation on Cognitive Function in The Elderly: A Systematic Review and MetaAnalysis. Drugs Aging. 2019;36(5):419-34.

13. O'Connor DMA, Laird EJ, Carey D, O'Halloran AM, Clarke R, Kenny RA, et al. Plasma Concentrations of Vitamin B12 and Folate and Global Cognitive Function in An Older Population: Cross-sectional Findings from The Irish Longitudinal Study on Ageing (TILDA). Br J Nutr. 2020;24:1-25.

14. Strub RL, Black FW. The Mental Status Examination in Neurology. $4^{\text {th }}$ ed. Philadelphia: F. A. Davis Company; 2000.

15. Maryati $H$, Bhakti DS, Dwiningtyas $M$. Gambaran Fungsi Kognitif pada Lansia di UPT Panti Werdha Mojopahit Kabupaten Mojokerto. Jurnal Metabolisme. 2013;2(2):16.

16. Pratiwi CU, Marliyati SA, Latifah M. Pola Konsumsi Pangan, Aktivitas Fisik, Riwayat Penyakit, Riwayat Demensia Keluarga, dan Kejadian Demensia pada Lansia di Panti Werdha Tresna Bogor. Jurnal Gizi dan Pangan. 2013;8(2):129-36.

17. Eitenmiller RR, Ye L, Landen WO. Vitamin Analysis for the Health and Food Science, $2^{\text {nd }}$ ed. USA: CRC Press; 2008.

18. Almatsier S. Prinsip Dasar IImu Gizi. Jakarta: PT Gramedia Pustaka Utama; 2009.

19. Ravaglia G, Forti P, Maioli F, Muscari A, Sacchetti L, Arnone G, et al. Homocysteine and Cognitive Function in Healthy Elderly Community Dwellers in Italy. Am J Clin Nutr. 2003; 77(3):668-73.

20. Ma F, Li Q, Zhou X, Zhao J, Song A, Li W, et al. Effects of Folic Acid Supplementation on Cognitive Function and $A \beta$-related Biomarkers in Mild Cognitive Impairment: A Randomized Controlled Trial. Eur J Nutr. 2019;58(1):345-56.
21. Ma F, Zhou X, Li Q, Zhao J, Song A, An $P$, et al. Effects of Folic Acid and Vitamin B12, Alone and in Combination on Cognitive Function and Inflammatory Factors in The Elderly with Mild Cognitive Impairment: A Single-blind Experimental Design. Curr Alzheimer Res. 2019;16(7):622-32.

22. Enderami A, Zarghami M, Darvishi-Khezri $H$. The Effects and Potential Mechanisms of Folic Acid on Cognitive Function: A Comprehensive Review. Neurol Sci. 2018;39(10):1667-75.

23. Health Quality Ontario. Vitamin B12 and Cognitive Function: An Evidence-Based Analysis. Ont Health Tech Assess Ser. 2013;13(23):1-45.

24. Kim H, Kim G, Jang W, Kim SY, Chang $\mathrm{N}$. Association Between Intake of B Vitamins and Cognitive Function in Elderly Koreans with Cognitive Impairment. Nutr J. 2014;13(1):118-28.

25. Smith PJ, Blumenthal JA. Dietary Factors and Cognitive Decline. J Prev Alzheimers Dis. 2016;3(1):53-64.

26. Kwok T, Lee J, Ma RC, Wong SY, Kung K, Lam A, et al. A Randomized Placebo Controlled Trial of Vitamin B12 Supplementation to Prevent Cognitive Decline in Older Diabetic People with Borderline Low Serum Vitamin B12. Clin Nutr. 2017;36(6):1509-15.

27. Blondell SJ, Hammersley-Mather R, Veerman JL. Does Physical Activity Prevent Cognitive Decline and Dementia?: A Systematic Review and Meta-analysis of Longitudinal Studies. BMC Public Health. 2014;14(1):510.

28. Muzamil MS, Afriwardi, Martini RD. Hubungan Antara Tingkat Aktivitas Fisik dengan Fungsi Kognitif pada Usila di Kelurahan Jati, Kecamatan Padang Timur. Jurnal Kesehatan Andalas. 2014;3(2):202-5. 